\title{
鎔接部の性質に影響する二三の要素に就て
}

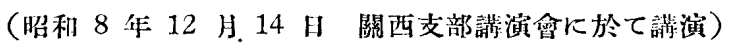

$$
\text { 正員工学士岡明實 }{ }^{(1)}
$$

\section{Some Factors of Influence to the Welded Part}

By Minorı Okada, Kôgakusi, Member

\begin{abstract}
摘要
軟鋼材鎔接部に影響する 5 つの要素（1）鎔接手の技倆（2）鎔接材料（3）鎔接設計 (4) 鎔接工法 (5) 電機器 に就て簡迅し鎔接材料特に鎔接棒に就て賽驗結果研究方針を示したものである。
\end{abstract}

緒訔

最近電气鎔接が造船、建築、機栈構浩その他あらゆるす面に 普及發澾して然も相當重要視されて居る。從つてこれに對す 万哳究も世界的に着々と進如られて居り、私も菲才を顧みず この新しい工業或は工学方面に関係をもつて若干研究してる るのでその 1 部であるが鎔接部の性質がどんなものによつて 影響されるか又それに對應する方法としてどんなことをすれ ばい১かに就て極く原則的なことを簡單に申述べたいと思ら 然し電气鎔接の中には抵抗鎔接もあれば電弧鎔接もあり原 子水菜鎔接の如き特殊のものむある。けれども私が述べるの は金屬電極を肘ひ弧光熱を利用する所謂金屬電弧鎔接の場合 に限る。又鎔接すべき材料も炭素鋼だけでも種々あり特殊 鋼、非鉄金屬材料になれば殆と數へ得られない程ある。これ 等を鎔接する場合には夫々その材料の物理化学的性質或は治 金的機械的經過を知らなければ鎔接は到底うまく出來ないの で非常に研究する範圍は黄いのであるがこっには軟鋼材に就 てのみ記述する。設計上の諸問題とか應力計算等は私の專門 外のことで寧ろ御敉示を願ひたいのであるが二三簡單な事柄 に就て㬰上樣と思ふ。

㧋て鎔接部の性質に及佂す影響を大別して見ると私は次の 樣な 5 大要素があると思ふ。
1. 鉻接手の技倆
4. 鎔接工法
2. 鎔接材料
5. 電機器及び諸施設
3. 鎔接設計

鎔 接 手

今日電弧鎔接は特殊の物、或は特殊場所には自働鎔接が行 はれるがその他の殆ど大部分は人間の手で行ふ手働鎔接であ る。それで鎔接手の技術が非常に重要なことは中すまでもな いが、人間のことであるから體質とか氝質とか或はその時の 狀態によつて成績が違ふのであつて例へば常は非常にい〉仕 事をするものでも病肨とか不衞生をした後とか或は一日の中 だも夕方等は成績が低下゙する。又鎔接手が目已の仕事に自覺 をすつてるるかどうかによつて結果に非常に影響がある。

\section{(1) 大阪带國大学助敉授}

P. Marran が鎔接手の有すべき性質として鎔接技術を熟 練せしむべき職工の選擇には次の要件を充すものなるべしと 提議してるる。

1. 鎔接手は信賴し得るものたること

2. 鎔接手は勤勉なること

3. 鎔接手は才智があること

4. 鎔接手は Ambitious であること

5. 鎔接手は決斷力を有すること

6. 鎔接手は體質が仕事に適すること

鎔接手の選擇は普通の職工より以上に充分注意する必要が あるが然し鎔接手の技雨は天才的であることを要しないで寧 ろ通常の出來榮人でも一定確實な仕事をすることが必要であ る。近頃これ等の考へは相當認められて鎔接手には中等学校 卒業程度のものを探用する向が多いことは鎔接工業の信賴性 を助長する、に結構なこと〉思ふ。

\section{鎔 接 設 計}

著者が實驗の際に感じたこと文び二ニの實際上の問題に就 て簡單に記述する。

1. 應力の分布をなるべく均一にする

衝合鎔接ではその削稜方式によつても變り、鎔接線に就て 云一ば鎔接を適當に分㓶することによつても變る。

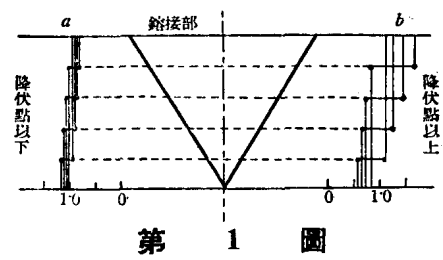

鎔接部は一般に鑄造組織を呈し延伸性が少くないのである から隹力が集中しやすく殊に振動、繰返し荷重、衝摮等を受 けるものでは特に注意を要するのである。

鎔着金屬は鋼鈑より彈性係數は稍小さく彈性限を越一てか ら延伸率が少く非常に脆弱なるのもあるので第 1 圖の如き衝 合鎔接を V 型削稜で行つた接手に張力が作用したとすると彈 性限までの荷重であれば應力分布は左圖 $a$ の如く原鈑部に集

昭 和 9 年 10 月] 


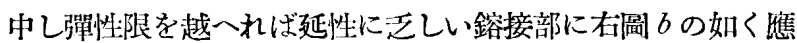
力が集中し端の部分に最大の隹力を生ずることになる。

尤も軟鋼でも鎔接部近くの原鈑は過熱急泠されて相當硬化 するのと鎔者金屬中の $\mathrm{C}, \mathrm{Mn}, \mathrm{Si}$ ，等は非常に少くなつて るるのでト圆の如き階段的にならず順次硬化傾向を示す場合 が多い。然し鎔接部に合金元素を加へた場合等には著しく、 硬化して應力が集中 し、逆に原板の炭素量 が多いとか特に强趾な むのであるときは鎔接 部の硬度は原鈑より低

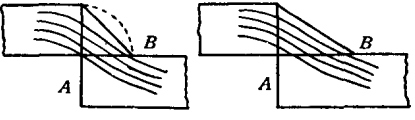

(a)

第 2

(b) くなる。

けれども應力分布を出來るだけ一漾ならしむることは考慮 を要する點であつて殊に厚鈑鎔接に必須の事柄である。これ に對し例へば I 型 U 型 H型等種々な㓩棱方法がある。

前面隅肉鎔接では第2 圖の如き接手に於て $A B$ に隹力が 集中する。力線の集中を楥和するには $b$ の如く脚 $A B$ を長 くする方法もある。

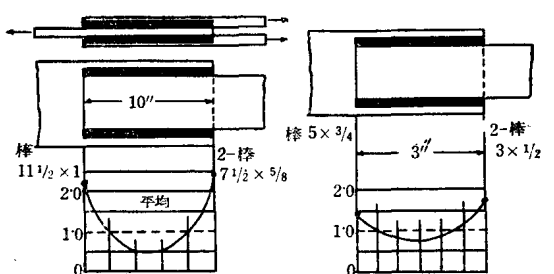

3
側面隅肉鎔接 では應力分布は 第 3 圖の如くに なり端に集中す る。疲勞破壇を 起す虞のあるす のは特に注意を 要し、例一ば斷 續鎔接をなすとか鎔接配置を考虑するとか適當な方法を講じ なければならない。

上記の簡笚な添明に依つても前面隅肉鎔接と側面隅肉鎔接 を區別することが必要と思ふ。
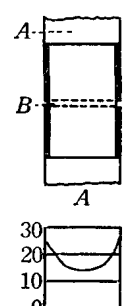

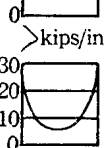

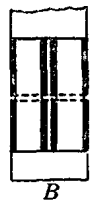
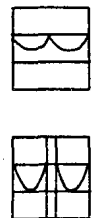
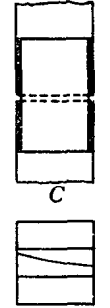

断面 $A A$

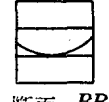

断面 $B B$
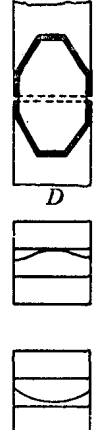
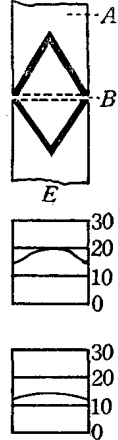

第 4 圆
接合線の應力分布を一樣にする例として第 4 圖の如く鎔接 分布をかへることによつて相當好結果を得ることが出來る。

繼續鎔接をなしその間を气办密或は水密にする筑に輕鎔接を 行ふときは輕鎔接に應力が集中する盧がある。これ等の鎔接

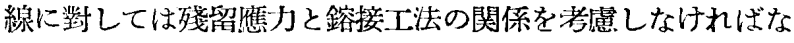
らない。

2. 彎曲力率をうける部分はなるべく避けること文は特に 考淄を拂ふこと
鎔接部は届曲に對する抵抗が比較的小であるから鎔接材料 を特に吟味し或は熱處理を行ふ䅵な場合の他はなるべく少く することが肝要である。從つて部材を接合するにも對稱形が 好しく第 5 圖 $A$ より $B$ を探用寸べきである。杜に析を接合す る場合等も先づ杜にブラ
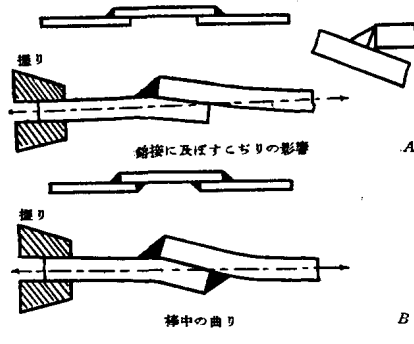

第 5 圖 ケットを附け且ブラケッ トの鎔接は計算にに垂直 部分で充分であつても第 6 圖の如く上部の水平部 分を鎔接して風性を大な らしめ屈曲を避ける樣に 設訫すれば安全且有効で ある。然し對稱形と雖も 鎔接線の集合により材質 が熱影響をうける場合は避けなければならない。
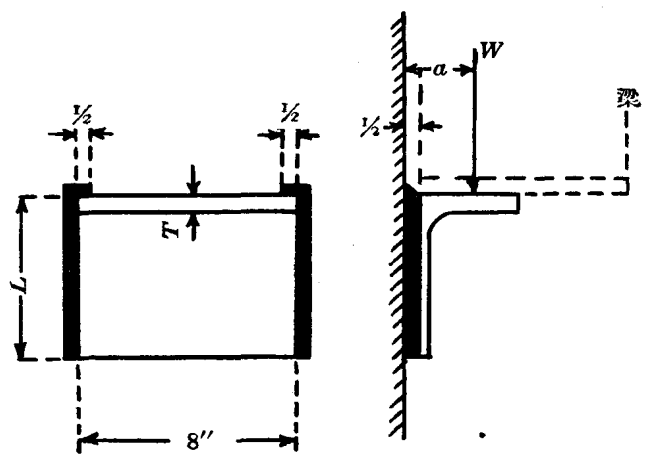

3. 鎔接作業が容易な設計をなすこと

工場でも現場でも鎔接棒を遮當の位置に保つて作業出來る だけの空間を準備して置かなければ鎔接結果を低下する。上 向鎔接は出來るだけ少くし工場で鎔接する樣に設訫すること が大甽である。又設計が鎔接に適しない鴬に鎔接結果が惡く なる場合もある。例入ば杜に桁を㨁結する設計では實際上仕 上寸法が非常に困難になり、又相當正確に出來ても實際現場 で鎔接する場 合には沿間隙 が大きすぎる こともあり得 る譯だから澤 山の盛金をし て且結果がよ くないことに なる。
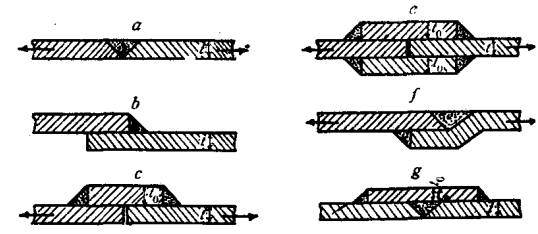

4. 接手の形と効率

接手の形を色々工夫する事によつてその强きも變り鎔接設 計上安全性を增大せしむることが出來るのである。第 7 圖は 獨逸鎔接協會の計算に從ふ各接手の效率を示したものである

$$
\begin{array}{ll}
\cdot a=60 \% & \cdot e=84 \frac{t_{0}}{t}-\% \\
\cdot b=42 \% & \cdot f=84 \% \\
\text { - } c=42 \frac{t_{0}}{t} \% & \cdot g=\left(60+42-\frac{t_{0}}{t}\right) \%
\end{array}
$$

[第 37 卷 第 210 號 


$$
\text { - } d=84 \% \quad \cdot h=\left(60+42 \frac{2 t_{0}}{i}\right) \%
$$

5. 隅肉の大さと强さの関係

隅肉上の應力分布は上述の如く側面隅肉と前面隅肉で趣を 異にするが從來の計算法と實驗結果から大體に㗱の厚さに比 例して强さが樰大するものと認められてるる。從つて强さと 鎔接量の関係は筫際作業に重要である。今隅肉の大さ（㨁角 三觕形隅肉とす) と强さ但し鎔接部の許容應力を $800 \mathrm{~kg} / \mathrm{cm}^{2}$ とす）及び隅肉面啧の関係を表示すれば次の如くである。

\begin{tabular}{|c|c|c|c|}
\hline $\begin{array}{c}\text { 隅肉の大さ } \\
\mathrm{cm}\end{array}$ & $\begin{array}{c}\text { 單位憵力 } \\
\text { g/cm }\end{array}$ & 比 & $\begin{array}{l}\text { 面積 } \\
\mathrm{cm}^{2}\end{array}$ \\
\hline 0.9 & 500 & $1 \cdot 00$ & 0.540 \\
\hline $1 \cdot 2$ & 680 & $1 \cdot 36$ & 0.72 \\
\hline 1.6 & 900 & $1 \cdot 80$ & $1 \cdot 28$ \\
\hline $2 \cdot 0$ & 1,130 & $2 \cdot 26$ & $2 \cdot 00$ \\
\hline
\end{tabular}

上表に於て $9 \mathrm{~mm}$ 隅肉を標準として求めた比の如く强さに 對してはあまり隅肉を大きくしないうが材料が有効であり作 業時間を相當に短縮し得ることが分るのである。

衝合鎔接の刢棱を V 型より I, U, H 型にすることは前述 の如き隼力分布を均一ならしめる外に厚鈑に於る鎔着量の唔 加を少くするに效果がある。構浩物ではあまり厚いものを报 ふ場合が少く $9 \mathrm{~mm}$ 或は $12 \mathrm{~mm}$ 程度が多くこの懸念は少 いが隅肉鎔接で厚鈑を接命する場合㑬稜に對し考一をもつこ とは必要と思ふ。

\section{鋑接捧之鋊着金屬の關係}

鎔接の材料とは原鈑即ち鎔接される鋼鈑と鎔接棒とであつ て鎔接される原 鈫によつて鎔接 棒を變へなけれ ばならぬことは 吻論であるがそ れには鎔接棒を

\begin{tabular}{|c|c|c|c|c|c|c|}
\hline 鋊接棒 & $\mathrm{C} \%$ & $\mathrm{Si} \%$ & $\mathrm{Mn} \%$ & $\mathrm{P} \%$ & $\mathrm{~s} \%$ & 考 \\
\hline 1 & $<0.06$ & $<0.08$ & $<0 \cdot 15$ & $<0.04$ & $<0^{\circ} 04$ & 米國鎔接協會规格 $\mathrm{A}$ \\
\hline 2 & $0.13 \sim 0.18$ & $<0.06$ & $0.40 \sim 0.60$ & $<0.04$ & $<0.04$ & $\prime \prime$ \\
\hline 3 & $0 \cdot 12$ & 0.017 & 0.39 & 0.04 & $0 \cdot 05$ & 著 者 試 驗 村 \\
\hline 4 & $0 \cdot 05$ & $0 \cdot 012$ & $0 \cdot 46$ & $0 \cdot 06$ & 0.06 & $\prime \prime$ \\
\hline
\end{tabular}
鎔接部にとかした場合に成分組織等がどんなに變化するかを 知らなければならない。軟鋼の鎔接には非常に低炭素の鋼線 が用ひられその組成は上表の如くである。

鎔接棒 3 を用ひて鎔着しその組成を分析した結果は次の如 くである。

$\begin{array}{cccccc}\text { 極 性 } & \mathrm{C} \% & \mathrm{Si} \% & \mathrm{Mn} \% & \mathrm{P} \% & \mathrm{~S} \% \\ \text { 鎔按棒+ } & 0.01 & \text { 痕䟞 } & 0.10 & 0.04 & 0.08 \\ \prime \prime-~ & 0.01 & \prime \prime & 0.11 & 0.04 & 0.08\end{array}$

裸棒は直流では充分仕事が出來るが交流では作業が困難で あり大氝の影響を緩和防止する等の焦に普通は被覆齌を塗つ てるる。裸棒を鎔羙した場合でも電流の强さ Weaving の大 小運棒方法等によつて鎔着金蜀の組成は相當に變化する。又 元素によつてその變化が異り、或るものは筜加し或るものは 減少する。例一は酸素窒素量は著しく霄加し燐、硫黄、銅、 ニッケル等は殆ど不變或は㬐加の傾向があり滿俺、硅素、炭 素は著しく減少する。被覆劑を加一たときは更に變化に相違 があり弧光中或は熔融中に於ける鉄中の元素量の變化は䐝際 昭 和 9 年 10 月]
電弧の安登に は金屬酸化物が 適當でありまた 鎔接幾の負荷特 性に應じ弧光電 压をか一る必要

問題として非常に難題でこれに適隹する使用法を㯖得しなけ れば鎔接棒の県價を發揮することが出來ない。然し大體の倾 向は種々な試驗により推察することが出來る。

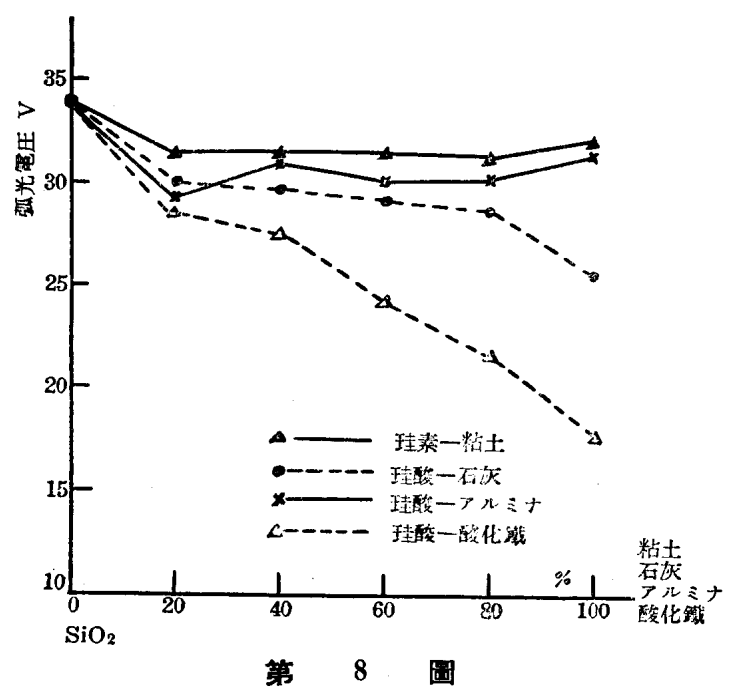

今日市場には色々な鎔接棒が賣比されて居るが定性的に相 當優秀なものもあり又極めて粗惡なものもある。この相違は 刎諭芯線に因る場合もあるが垫線が略同一でも被覆劑の適否 に因つて起る。被覆劑の目的の中重要なものは次記の如くで あると思ふ。

1. 電弧の安定と弧光熱の集中

2. 有效鑛滓の生成

3. 脫酸或は材質改良

のある場合は第 8 圖の如く酸化鉄、石灰等は弧光電匡を下げ 硅酸、粘土等は電匟を.上昇する。

これと同時に弧光を鎔接部に集中する傾同があり熱の放散 を防ぎ熱エネルギーの有效率を高める。

次に艮い鑛㵏を作ることが治金術七最も重要な如く鎔接の 場合でも鎔接部がい〉焦には鏬滓が虔くなければならない。

鑛滓の熔融溫度は $800^{\circ} \mathrm{C}$ 乃至 $1,200^{\circ} \mathrm{C}$ て流動性に富み且 表面張力が小なることを要する。アルカリを含む第 1 珪酸鉄 が大體この要求に適する樣でする。

脫酸に對しては滿俺鐵、珪素鐵、アルミニゥムが製鋼で嘠 ひられて属るがこの中硅素は鐵と結合しやすく鎔鐵の熔融溫 度をトけゲ作業が困蜼になり、且砫素は結晶粒の 成長を起し 弱くなる盧がある。アルミニゥムは殆ど弧光中或は鎔鐵中で 酸化消失するから脫酸效果は底好であるが過量に入ると硅素 の場合の如くになる。滿俺は硅素等と反對に鐵の $A_{3}$ 變態點 をドげ粒の成長を起すことがなく脫酸效果す艮效である。

鎔着金屬の改良には目的に隹じて合金元素を適量加一れば 
或る程度まで要求に近づけることが出來る。又 Shieled Arc を生じて大氠の侵入を防護し酸化物、窒化物の生成を避ける 焉に還元ガスの生成、厚被覆棒等も鎔着鐵の性質改是に効果 がある。合金元素を加へるとき抗張力を增すには $\mathrm{C}, \mathrm{Ni}, \mathrm{Cr}$, $\mathrm{Mo}, \mathrm{Mn}, \mathrm{V}, \mathrm{W}, \mathrm{Ti}$ 等の諸元素があるが前述の如く元素の 種類によつて鎔着鐵中に入る量が非常に違ひ、著者の研究に よれば被覆劑中に入れた場合は第9 圖の如くなる。圖中太い

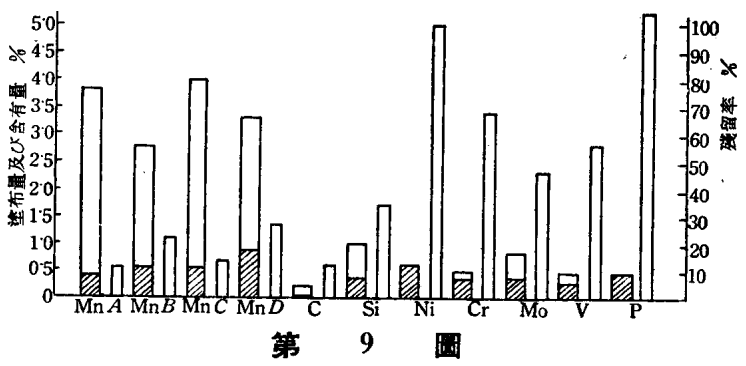

白線は被覆量、影線部は殘留量、細線は殘留率を示す。Weaving の大小、鎔接速度、被覆劑の種類、量等に依つて殘留菜は 變るのでこの1例として減少の多い滿俺の湯合を示すと $\mathrm{Mn}$ A は滿俺鐵粉を塗り青石綿で被覆した $4 \mathrm{~mm}$ 径、 $45 \mathrm{~cm}$ の 鎔接棒で $110 \mathrm{~A}$ の電流を通じ鎔着の長さが $10 \mathrm{~cm}$ のとき、 $\mathrm{MnB}$ は滿恢鐵を淕つた上に更に塗布劑を塗り電流を $120 \mathrm{~A}$ で $10 \mathrm{~cm}$ に鎔着した場合、 $\mathrm{MnC}$ は $\mathrm{MnA}$ と同樣のものを $15 \mathrm{~cm}$ に鎔着したとき $\mathrm{MnD}$ は $\mathrm{MnB}$ と同じものを $15 \mathrm{~cm}$ に鎔着した場合で各々相㙔がある。

著者は經濟的見地から满俺を主成分とし鎔着金臀の强出を 試驗したがその結果は次表の如くで更に合金元素をか一適量 をあたへれば 70 $80 \mathrm{~kg} / \mathrm{mm}^{2}$ の强さも得られる。

\begin{tabular}{|c|c|c|c|}
\hline 番暍 & 被敖劑 & 主要合金元素 & 力 $\mathrm{kg} / \mathrm{mm}^{2}$ \\
\hline 1 & 青石㸡 & $\mathrm{Mn}, \mathrm{Mo}, \mathrm{V}$ & $60 \cdot 36$ \\
\hline 2 & $\prime \prime$ & $\mathrm{Mn}, \mathrm{Ni}, \mathrm{Mo}, \mathrm{V}$ & $62 \cdot 57$ \\
\hline 3 & " & $\mathrm{Mn}, \mathrm{Cr}, \mathrm{Mo}, \mathrm{V}$ & $57 \cdot 90$ \\
\hline 4 & 塗布利 & $\mathrm{Mn}, \mathrm{Mo}, \mathrm{V}$ & $53 \cdot 03$ \\
\hline 5 & $\prime$ & $\mathrm{Mn}, \mathrm{Cr}, \mathrm{Mo}, \mathrm{V}$ & $60 \cdot 41$ \\
\hline
\end{tabular}

又著者の研究によると鎔羙金屬の導磁率を高らしめ衝擊抵 抗を大ならしめるには Mn, Si，の適量を共有するものが適 當である。

\begin{tabular}{|c|c|c|c|c|}
\hline 容着材 & $\mu \max$ & $\begin{array}{c}\text { 履歷損失 } \\
B=15,000 \\
\mathrm{erg} / \mathrm{cm}^{3} / \text { cycle }\end{array}$ & $\begin{array}{c}\text { 抗張力 } \\
\mathrm{kg} / \mathrm{mm}^{2}\end{array}$ & 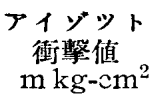 \\
\hline & 710 & 29,500 & $31 \cdot 4$ & 0.7 \\
\hline , $\mathrm{Si}$, 被 & $1,15 c$ & 15,300 & $46 \cdot 5$ & 3.9 \\
\hline
\end{tabular}

以上の如く鎔接都の性質は合金元素を加一ることにより或 る程度まで變へることが出來るが鎔融鎔接は 1 種の鑄浩であ り又續く鎔接熱によつて不完全な熱處理等も受ける特斾な場 合である故に到底適當な調質をうけた材料と同樣にはならな い。從來の研究は既存の材料を如何にして鎔接するかにあつ て鎔接材料としての原鈑に對してはあまり考一られてるない が今後は鎔接すべき原鈑の選擇が鎔接結果に至大の影響があ るのは見逃せない。㱠ど不可能に近い材料の鎔接を强要され ることは鎔接手は勿論現場從業員の苦㛴一通りでない。著者
の實驗したジュコール鋼の如き滿俺と炭素を主成分とし何れ をかへても同じ抗張力が得られると云ふ場合滿俺が多く炭素 が少いものは燒制とか硬化が少く滿俺が少く炭素の多い場合 は燒慗等の庭が多い。叉デリケートな調質をうけた材料は鎔 接によつてその優秀な性質を全く失ふこともある。

\section{鎔接棒研究の方針}

上述の如く市場には各々秘訣を有つ鎔接棒があるが分析等 によつてその組成を知ることが困難であり、研究も多船に步 るので鎔接棒に關する文献は稀であり各目の研究を强ひられ てるる現狀である。然し著者が經驗上提唱したい研究の方針 は次の如くである。

1. 芯線 垫線の成分及び組織は冶金学的研究を要するの であつて化学分析により組成を決定し顯微鏡試驗その他の 治金学的試驗を用ひ忐線の諸性質を決定しなるべく不純物の 少いもの殊に燐、硫黄等の少いるの又偏析その他物理的不㘬 一のなきむのを選擇しなければならない。低炭素鋼線の炭素 量は熟練すれば線の輝いた面の色によつて推定することが出 來る。

2. 被覆劑の熔融點 沂來鐉滓、ソルトバス等の研究に平 衡狀態圖が活用され又平衡狀態圖の研究も非常に進步したの で被覆劑の熔融點推定も比較的容易になつて居る。例一ば砫 酸と一酸化鐵の系では硅酸 $23 \%$ 及び $38 \%$ に共晶點があり $30 \%$ 及び $44 \%$ に化合物がある。共晶溫度は夫々 $1,150^{\circ} \mathrm{C}$ 及 び $1,115^{\circ} \mathrm{C}$ 又硅酸と過酸化曹達との系では $\mathrm{Na}_{2} \mathrm{OSiO}_{2}$ 及び $\mathrm{Na}_{2} \mathrm{O}_{2} \mathrm{SiO}_{2}$ なる化合物があり、融點 $1,088^{\circ} \mathrm{C}$ 及び $874^{\circ} \mathrm{C} て ゙$ ある。硅酸、一酸化鐵、過酸化曹達を適當に組合せば $800^{\circ} \mathrm{C}$ 乃至 $1,200^{\circ} \mathrm{C}$ 位の熔骶溫度を得ることは哀易であり實際に靑 不綿は主として上記 3 成分を含み熔融點 $900^{\circ} \mathrm{C}$ 乃至 $1,000^{\circ} \mathrm{C}$ で鎔接に適する被覆劑の 1 つである。

3. 表面張力 現在鎔劑の表面張力は測定された記錄が殆 と無くどう云ふものが適常か、䀝定出來ないが粘士、酸化鐵 等の鑛滓はかたまり易く炭酸曹達等を加へたものは流れがよ く擴り易い。

4. 鏬㵏つ气泡 鎔接部上の鑛㳯をとるに㭙間がかつつて は仕事の能率が惡く職工がこれをおろそかにし折角の鎔接部 を臺なしにすることがあるので多層鎔接の湯合鐄滓は出來る だけ除去しやすいものでなければならない。それに對し鑛㳯 が气泡に富んでるるときは輕い鎚打でパラパラになり又鑛漳 の存在が明膫であるから職工が見落すことが少い。裸棒とか

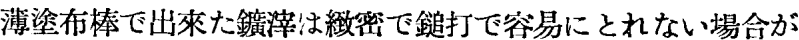
ある、第 1 硅酸鐵のマンガンを含んだもの等は鑛㴖が多孔質 で不灰、酸化鐵の多いものは緻㗼である。

5. 弧光電压 弧光電压の高いものがい〉と云ふ須と低い のがい〉と云ふ說があるが各々得失がある。例人ば高いもの は鎔接機の端子電压を高くしなければなら始から危險性があ り文作業の問題として薄鈑には穴をあけやすい。これに反し 低いものは鎔达が少く充分な鎔盖が得がたい。又同一電力と すれば弧光電压の高いものより電流を多くしなければならな いから鎔接棒が灼熱し作業を困難ならしめることがある。そ 
の他種々な條体があるが著者は薄鈑を除いては幾分弧光電王 の高い方がい〉と思ふっこの弧光電王の調整は實用の範圍で は磪酸粘士等は高く石灰酸化鐵は低くなる。

6. 脫酸劑合金劑、前述の如く目的に應じ適量を決定し添 加しなければならない。

7. 弧光の安定 これは被覆棒ではあまり問題でないが場 合により弧光の消隇に惱むことがある。その原因は鎔接機の 特性との關係、鑛滓の性質にあつて例一ば硼砂が多いと弧光 が消滅しやすい場合がある。

8. 飛散菜 著者の筫驗によれば 10 30\% 飛散するが裸 棒よ少く炭酸曹達アルミニゥムの多いもの等は大きく飛ぶ傾 向がある。

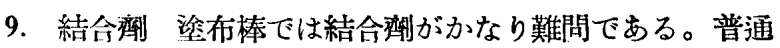
用ひられてるる結合濟俄水硝子、アラビヤゴム、フノリ、糊、 ニカワ、カゼイン等でこの內水硝子が一番多く使用されてる

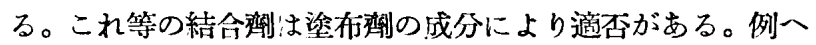
ば生不灰、重曹、アルミニゥム粉は水碑子では固着しない。 又アラビヤゴムを多くすると乾燥した後に龜裂が入りパラパ ラ落ちる。フノリは此較的無蜼であるが結合力が小さい。

10. 浢布の仕方 鎔接棒の全面に一樣に均一に塗ること に注意を要す。著者が塗布劑をつけた棒を垂直に保つて乾燥 したところ下端 $3 \mathrm{~cm}$ の準布量は 上端 $3 \mathrm{~cm}$ 間の約 2 倍に達し た。これは縱の位置についてら゙あるが横率面も均一につかな ければならない。望布量は芯線に對して $1 \%$ 以下から50\%以 上に達する厚いものまであるが作業と合せ考入て著者は作業 中 Molton pool が見える程度で愿い方がいとと思ふ。從つ て 5\% 20\%位 が適當ぢやないかと思ふ。

11. 鎔着鉄の破面 鎔接棒の研究に一タ試驗片を作製し 精密試驗をすることはもとより望しい事であるが簡單に破面 で底否を判別することも有效である。破面にはキラキラした 結晶を出す場合があるがこの時は針狀組織或は結晶の巽常な 成長をしたものである。軟鋼破面の如きときは艮好である。 又氝泡の存在む一瞭然である。

\section{銨 接 丁 法}

鎔接工法中重要なことは鎔接準備、鎔接順序及び鎔接棒の 位置、渾棒方法等種々あるが器具の整備と共に鎔接手が作業 するに容易な染勢を得る樣な設備が必要である。例一ば著者 の體驗よりしても高愿建築上で作業する場合等は足場の完全 なことを希望して止まない。鎔接手注作業中は殆と䟥止狀態 で冬は寒風に夏は炎熱に曝され乍ら寸特も鎔接部から他に注 意を頒ち得ないのであつて若し他に注意を拂はなければなら 奴樣では鎔接手つ疲勞が激しく鎔接成績も非常に低下゙する。 地線の位置む鎔接の難易を支配する1つの要素で厚物ではこ の影響が相當に表はれ弧光炤が一ガにのみ集中する場合があ る。著者の經驗では地線を鎔接線上に置くのがいつ樣に思ふ 電流及び電压を適當にして鎔接する場合も鎔接順序は最初 によく吟味して置かなければなら奴。接手の型式により殘留 昭和 9 年 10 月]
應力の性質が異り又鎔接順序、方法等によつて接合型式が變 ることもあり、殘留隹力の量も非常に變化する。奀を少くす ることが大切なことは云ふまでもないが同特に殘留應力の少 い接合が出來る樣に鎔接順序を選ぶ必要がある。

例一ば圖の如き場合 12 をつけて 34 をつければ nonrigid 型或は Semi-rigid 型で残留應力も少く接合山來るが 34 を先きに固着して 12 をつけると fixed 型になつて

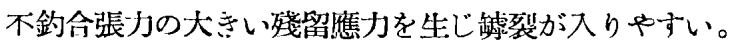

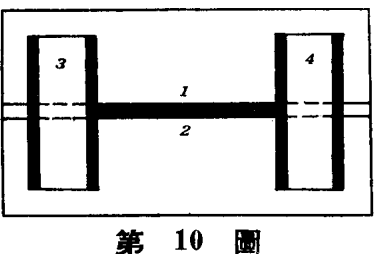

又累層の順序も殘留應力並に歪に多大の 影響があるが Wide Weaving は如何なる場合も好しくない。原鈑と鎔着 を充分にする程度で Weaving は出來るだけ狹くした方が い〉と思ふ。前述の如く滿俺等を含むものでは鎔接棒の位置 と蕅棒方法は結果に對し 至大の 影響を有しWeavingを少 くしなければ一淁な鎔着は得られない。

次に鎔接棒の原鈑に對する傾牦は鎔接棒に特有の最底位置 があるが大體に弧光電压の高いもの被䪖の厚いものは傾かせ 弧光電压の低いもの被覆の薄いものは立たせた方が適當の樣 である。勿新棒を傾かせることも鎔接線上鎔接方向に傾かせ るので鎔接棒を原鈑の何れの方にも傾かせてはならぬ。鎔接 手は各目多少の癖がある故鎔接棒の傾き方等は指導者が注意 しなければなら奴。鎔接中 Molton pool の狀態に注意を 要し、鏈筝狀態で㠜固して行くものは概してよく激しく動搖 或は盛上るものはよくない。鎔接の第 1 椾で底をよく熔すこ こは最む大切で殊に隅肉鎔接では底の熔け工合を衝合鎔接の 如く見ることが出來ないので注意を要する。熔融が充分でな いときは屈曲等の荷重を受けたときは㗱桓闻の娍少以上に應 カが集中して接合效率を低ドせしめる。

\section{電 气機 械}

電氝機峨の性能は鎔接に對する邂否の外に多くの要素が命 まれる。例一ば電擎の危險、電源の性質、電力料、力索、機 械の價格等がありこれ等は鎔接作業の容易なるべき佟件と相 反する場合が多い。從つて鎔接機の製作或は購入は實際上相 當考慮を要する問題である。

值流機は大體に弧光が安定で作業が容易であり鎔接結果も 良好である。交流機は交番に從つて弧光の停止があり從つて 不安定になる傾向がある。然し近頃は殆ど被皦棒が用ひられ て居り弧光の安定はあまり問題でなく特殊材料或は特殊の場 合を除く外軟鋼材の鎔接には交流機でも作業は容易である。

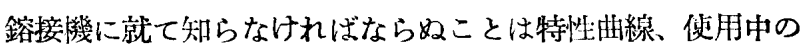
溫度上昇、交流機では特に無負荷端子電区等である。 
然し鎔接機の砰究も相當に進み今日定評あるものは普通の 鎔接には殆と交障なく鎔接機よりも寧ろ取报上の可否例一ば 電流の調整、保持器の損㑺、スクリーン、ハンマー、ブラシ等 の不光全な笉鎔接部の性質に多大の影響を與へる虞がある。 文献:

P. Marran Journal of American Welding Society October 1932.
H. M. Priest Journal of American Welding Society August 1933

阙田、藤原鎔接協會誌 鎔接協會誌

昭和 8 年 4 月

岡细

機械 I. 学

鐵 と 鋼
昭和 8 年 8 月

昭利 8 年 5 - 8 月

昭和 9 年 7 月 